$\begin{array}{ll}\text { Indedia } & \begin{array}{l}\text { InMedia } \\ \text { The French Journal of Media Studies } \\ \\ \text { Global Film and Television Industries Today }\end{array}\end{array}$

Media Studies: A French Blind Spot

François Cusset

(2) OpenEdition

Journals

Electronic version

URL: http://journals.openedition.org/inmedia/135

DOI: 10.4000/inmedia.135

ISSN: 2259-4728

Publisher

Center for Research on the English-Speaking World (CREW)

Electronic reference

François Cusset, « Media Studies: A French Blind Spot », InMedia [Online], 1 | 2012, Online since 16 March 2012, connection on 08 September 2020. URL : http://journals.openedition.org/inmedia/135 ; DOI : https://doi.org/10.4000/inmedia.135

This text was automatically generated on 8 September 2020

(c) InMedia 


\title{
Media Studies: A French Blind Spot
}

\author{
François Cusset
}

1 Within the French university system, teaching or simply promoting Media Studies, according to the Anglo-American tradition, sometimes feels like teaching marketing in 1950s Soviet Union: an odd choice, both exotic and risky, going against the grain of dominant norms. Indeed there is not a single course Major or Minor, nor any full curricular program in Media Studies, within the realm of French higher education. The only attempt in this direction can be found in a few departments of "Information and Communication Science" (dubbed "Infocom" in the French academic lingo), but in the form of highly specific approaches of the media landscape, from reception studies to the sociology of journalists and to the stakes of new information technology, rather than the quintessential Media Studies comprehensive interdisciplinary approach. As if all there was in France was a scholarly and critical dead zone, an empty territory waiting to be explored, between France's two dominant-and exclusive-takes on the subject: non-academic activism against media power and bias, and the purely technical professional training of journalists.

2 On the one hand, the French way of theorizing and investigating the media world consists in a deliberately biased and ideologically committed critique of dominant media, in the wake of the age-old critical paradigm (derived from the Frankfurt School's totalizing and oppositional approach, developed first by Theodor Adorno and Max Horkheimer, as well as from various post-Marxist media watchdogs), but clearly removed from academic circles. What is at stake here is an adamant critique of mainstream media's agenda-setting function and the banana-republic type of privileges enjoyed by the French media elite. This is indeed a sound and useful view, best represented by online watchdogs of the Leftist sort such as Acrimed or Indymedia, and by the best-selling polemical essays by various editors of the critical monthly Le Monde diplomatique, such as the 1997 Les nouveaux Chiens de garde by Serge Halimi (over 300,000 copies sold and ten reprints) and the recent L'Explosion du journalisme by Ignacio Ramonet, ten years after his successful and aptly titled La Tyrannie de la communicationbut it is a view which is short on scholarship and the workings of interdisciplinary studies, to say the least, and which rarely appears in academic seminars and reading lists. Variations on such critical, non-academic approaches include former TV 
journalist Daniel Schneiderman's Webtv talk show "Arrêt sur images" and his own bestselling essays, as well as more recent publications, aimed at journalists and lay people alike, on the rise of online media and the more accurate, interactive, citizen-supported newsmedia it is currently striving to bring to life.

On the other hand, when the media world is the object of curricular programs in France it is most often, if not exclusively, in journalism schools and graduate programs in communication, which all have in common a professionalizing and vocational bent largely incompatible with an exhaustive cultural and social interpretation of media apparatuses. With very few exceptions, such as University of Paris-Sorbonne's CELSA, the said programs are not very well ranked, nor are they necessary to a successful career in these fields, and it comes as no surprise that a very small number of French professional journalists and communication experts hold such degrees. In a way, the difference between French and Anglo-American systems here is reminiscent of the situation prevailing in fine arts or architecture: a specific, almost exclusively professional and technical training in France's schools of architecture and fine arts, which appears paradoxical in the country of prevalent intellectualism, and equivalent programs in the US and UK rich in art theory and urban philosophy, all the way to teaching Erwin Panofsky and Jacques Derrida to future painters and architects, in countries usually more easily associated with a pragmatic tradition.

4 A few reasons for such a state of affairs can be briefly delineated, although each of them would require longer developments to be fully relevant. As with many byproducts of Anglo-American academic innovation over the past decades in the social and human sciences, which all met with strong resistance in France, one should first remember that the French university system, with its age-old disciplinary bastions, hasn't caught up yet on the many Anglo-American variants of inter- or trans-disciplinarity. Nor has it really joined a globalized academic field characterized by disciplinary crossings and interdisciplinary institutes-under whose auspices scholarly fields such as Women's Studies, Film Studies, African-American Studies, and Cultural Studies have seen the light of day over the past three or four decades. Nothing of that ilk in France, at least for now. Since Media Studies require the simultaneous practice of several disciplinary paradigms, if not their more ambitious interweaving to constitute the media as a new scholarly object, a country still reluctant to embrace such basic interdisciplinary bridgings as connections between literature and philosophy, or history and the social sciences, is guaranteed to not constitute the best academic home for Media Studies.

In that same respect, the wider French resistance to Cultural Studies, which Media Studies originally belonged to (in the pioneering works of David Morley and Stuart Hall, during the early UK phase of Cultural Studies), is a case in point: while Cultural Studies have been nurtured from day one by, among others, the works of Michel Foucault, Pierre Bourdieu, and Michel de Certeau, they have never 'made it' in France, where most scholars still see them as a playful 'American fad' (oblivious of their British birth in Birmingham in 1964), and-more profoundly-where the very concept of Culture, still sacred and somehow untheorized, is hard to relativize in terms of power relations and symbolic games. Maybe the exact same thing could be said in France of the media: not that it is as sacred and worshipped as a cultural (or literary, for that matter) Graal, on the contrary, but it is also taken for granted, turned into a natural phenomenon as much as the air we breathe, unworthy of an analysis in terms of social construction and cultural representation. Neither culture nor the media can easily be conceived of in 
France as a representational apparatus, a symbolic construction, a battlefield for identity politics (this taboo of France's colorblind 'République'), nor as an instrument of domination or resistance, despite the great legacies in these areas of Pierre Bourdieu and Michel Foucault. The case with culture might be a matter of religion (if one sees culture as France's only religion), whereas the case with the media could be a matter of contempt and cynicism: according to many French academics, this combination of lies and pressures, of promiscuous elites and conflicts of interest that constitutes the media should not be a serious object of academic study, period. It is too real, too contemporary, too trashy or 'pop,' to be worthy of a serious academic attention. In the same way that Anglo-American academics have developed a tendency to apply very elaborate theoretical tools to 'low' objects, such as pop culture or mainstream media, many French humanists tend to keep applying the same, unchanged rough conceptual tools to more 'noble' objects, which they view as the only ones worthy of their expert gaze (high literature, general anthropology, or vast political signifiers such as freedom or equality).

6 To conclude on a more positive note, there are indeed a few signs indicating that a Uturn might be taken in the not so distant future. Not only has French publishing started to translate the best of non-French theory which it had refused to import for so long (even if media theorists are still quite rare in French catalogs), and not only have issues of minority representation and reception theory started to be raised within the French media world (even if they have not yet been raised in more academic circles), but the French university system has come to acknowledge its belatedness with regards to the major theoretical debates of the globalized academic scene-and to half-open its doors to initial experiments in this direction, as with Gender Studies or with a serious approach to popular culture. Let us only hope that we won't have to wait for French media to improve its own standards of accuracy and professional rigor, and to become more hospitable to minorities and alternative views, before we finally see Media Studies taught in French universities. Because that might still take a long time.

\section{AUTHOR}

\section{FRANÇOIS CUSSET}

François Cusset lived in New York City for ten years, where he ran the French Publishers' Agency in the United States. He is currently a professor of American Civilization and the author of several essays on French-American relations, from the perspective of intellectual history. French Theory (University of Minnesota Press, 2008) and The Inverted Gaze: Queering French Literary Classics in North America (Arsenal Pulp Press, 2011) are among the most critically acclaimed. He is also a journalist, an editor and a translator and contributes his critical perspectives on both sides of the Atlantic.

Université Paris Ouest Nanterre La Défense 